\title{
Aplikasi Metode Join Inversi Seismik Gravity Untuk Imaging Dan Koreksi Statik Pada Daerah Geologi Kompleks
}

\author{
Triswan Mardani Ade Surya, Widya Utama, dan Firman Syaifuddin \\ Teknik Geofisika, Fakultas Teknik Sipil Dan Perencanaan, Institut Teknologi Sepuluh Nopember (ITS) \\ Jl. Arief Rahman Hakim, Surabaya 60111 Indonesia \\ e-mail:wdutama@yahoo.fr, firman@geofisika.its.ac.id
}

\begin{abstract}
Abstrak--Kondisi dekat permukaan kompleks terjadi ketika tubuh batuan beku atau karbonat terbawa dekat dengan permukaan. Keberadaan tubuh batuan tersebut dapat mengakibatkan perubahan kecepatan yang sangat signifikan. Permasalahan tersebut sangatlah sulit untuk diselesaikan dengan metode rekonstruksi kecepatan konvensional seperti tomografi waktu tempuh refraksi. Join inversi dari dua metode merupakan salah satu metode yang dapat digunakan untuk mendapatkan model kecepatan dekat permukaan. Pada penelitian ini digunakan metode join inversi travel time dan gravity untuk rekonstruksi model kecepatan dekat permukaan. Setelah itu dilakukan koreksi tomografi statik untuk mendapatkan posisi datum dan kecepatan lapisan lapuk. Penelitian ini menggunakan data sintetik gravitasi dan seismik. Data tersebut disintetik dengan metode talwani untuk data gravity dan elemen hingg untuk data seismik. Data seismik yang telah di forward kemudian dilakukan pemilihan first break untuk input tomografi travel time dan join inversi seismik gravity. Hasil dari metode join inversi seismik dan gravity memberikan model yang lebih baik daripada metode travel time tomografi. Perbedaan yang signifikan ialah adanya lapisan dengan kecepatan rendah yang terlihat pada model yang dihasilkan oleh metode join inversi dan tidak terlihat pada metode travel time tomografi. Selain koreksi statik dari model join inversi lebih baik dari segi kemenerusan dan kemiringan reflektornya.
\end{abstract}

Kata Kunci- Geologi kompleks, Join Inversi, Koreksi Statik. Travel time tomografi.

\section{PENDAHULUAN}

Geologi Kompleks adalah suatu kondisi dimana teknik imaging bawah permukaan konvensional tidak mampu bekerja secara maximum. Kondisi geologi kompleks terjadi ketika terjadi apabila perubahan kecepatan secara ekstrem baik secara horizontal maupun vertikal. Perubahan kecepatan yang ekstrem dapat diakibatkan oleh adanya body batuan yang memiliki kecepatan tinggi terbawa dekat permukaan contohnya adalah batuan beku dan karbonat [1]. Selain itu perubahan kecepatan dapat diakibatkan lapisan low velocity anomaly yang berupa sedimen batubara. Keberdaan anomaly tersebut hanya bersifat lokal.Umunya first arrival travel time tomografi mampu memberikan gambaran dekat permukaan secara akurat. Akan tetapi pada kasus geologi kompleks metode tersebut tidak mampu memberikan gambaran bawah permukaan secara akurat. Sehingga di perlukan data pendukung yang seinsitif terhadap keberadaan lokal anomaly seperti metode gravity [2].
Join inversi seismik travel time dan gravity merupakan salah satu metode tomografi yang dapat digunakan untuk mendapatkan gambaran dekat permukaan. Metode Join inversi seismik travel time dan gravity adalah gabungan dari dua metode tomography yaitu first arrival travel time tomography dan gravity inversion. Penggabungan kedua metode tersebut memanfaatkan teknik simultaneous joint inversion yang dimana pada prosess inversi, kedua metode tersebut saling mengkoreksi satu sama lain untuk menghasilkan model dengan error terkecil. Keuntungan aplikasi metode join inversi seismik gravity atau disingkat JSGI adalah mampu memberikan gambaran lapisan yang memiliki kecepatan tinggi ataupun rendah yang berada dekat permukaan. Selain itu model kecepatan yang dihasilkan oleh metode JSGI dapat dijadikan dasar penentuan datum dan kecepatan lapisan lapuk untuk melakukan koreksi statik pada pengolahan data seismik refleksi.

Tujuan yang ingin dicapai dalam penelitian penelitian ini adalah mendapatkan gambaran perlapisan dekat permukaan, melakukan koreksi statik pada data seismik dengan metode Travel time dan Join seismik gravity inversion. Manfaat yang ingin dicapai dalam penelitian ini adalah menjadi salah satu solusi untuk menyelesaikan permasalahan imaging pada daerah geologi kompleks.

\section{URAIAN PENELITIAN}

\section{A. Studi Literatur}

Pada tahapan ini hal yang dilakukan adalah pengumpulan jurnal dan buku yang menunjang penulisan penelitian. Selain itu pada tahapan ini dilakukan perencanaan dan penentuan model geologi berdasarkan jurnal-jurnal yang telah ada mengaplikasikan metode Joint seismik travel time dan gravity.

\section{B. Pemodelan Geologi dan Sintetik data}

Model geologi yang digunakan berdasarkan beberapa paper [3] tentang 3D Seismik-gravity Simultaneous Joint Inversion for Near Surface Velocity Estimation dan near surface solution in south rub al-khali untuk model sederhana dan complex PSTM sedangkan model serayu berdasarkan paper awang (2010) tentang potensi sub-vulcanik di Indonesia. Setelah dilakukan pemodelan geologi, kemudian dilakukan penentuan geometry shooting data seismik yaitu campuran 
antara push-end dan split-spread, dan dilakukan forward modelling data seismik maupun data gravity untuk ketiga model tersebut. Pemodelan data seismik dilakukan dengan menggunakan metode finite difference pada software Tesseral. Data gravity di forward menggunakan metode talwani pada software Tomoplus, Geotomo. Tahapan ini menghasilkan dua jenis data yaitu data gravity dan data seismik. Kedua data tersebut nantinya menjadi input utama pada penelitian ini.

\section{Picking first break dan imaging}

Tahapan picking first break pada data seismik merupakan tahapan yang sangat penting karena first break akan menentukan tingkat kebenaran model yang dihasilkan dari metode imaging travel time dan join inversi sismic gravity. Setelah picking first break dilakukan imaging dengan menggunakan dua metode yaitu travel time tomografi dan joint seismik gravity inversion. Gambar 2 adalah diagram alir imaging dengan mtode join inversi seismik gravity selama pengerjaan penelitian. Imaging menggunakan software Thrusline, Geotomo.

\section{Pengolahan Data Seismik}

Pengolahan data seismik dilakukan dengan cara menghitung parameter koreksi static, melakukan koreksi static, filtering (Bandpass, Deconvolution, TVSW (Time varian spectral whitening), FK filter, Radon Filter, FX Scadzhow, FX signal), PSTM, dan post processing. Gambar 3 adalah diagram alir imaging pengolahan data seismik selama pengerjaan penelitian. Pengolahan data seismik menggunakan software Thrusline, Geotomo.

\section{E. Penyusunan Laporan}

Tahapan Penelitian yang telah dilakukan dituliskan kedalam bentuk laporan akhir untuk lebih jelasnya tahapan pengerjaan penelitian dapat dilihat pada gambar berikut.

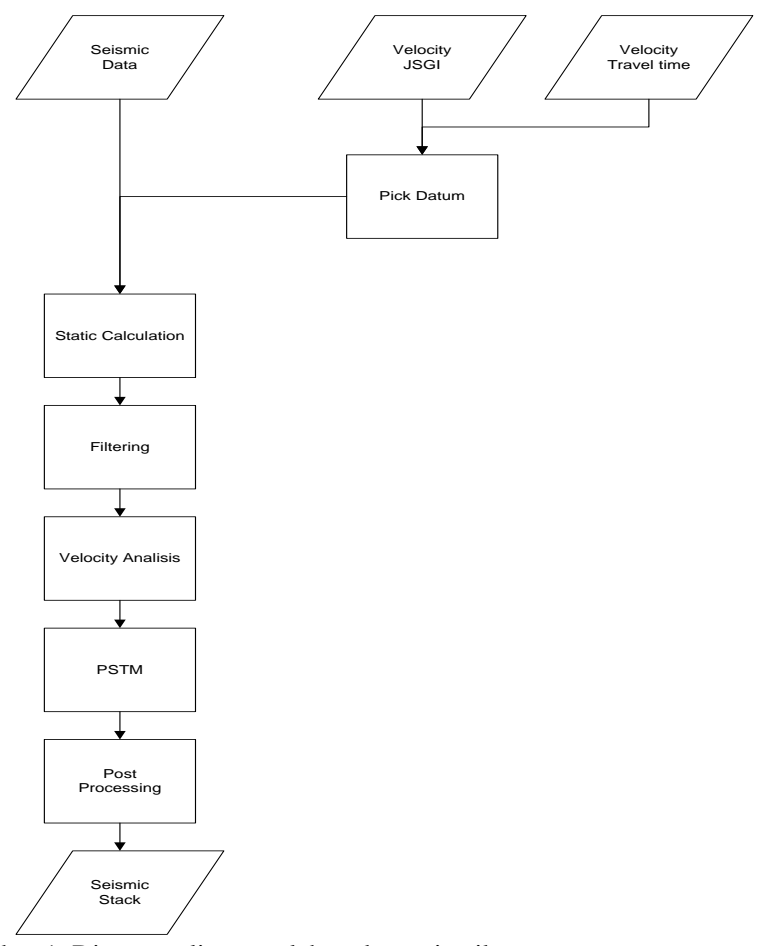

Gambar 1. Diagram alir pengolahan data seismik.

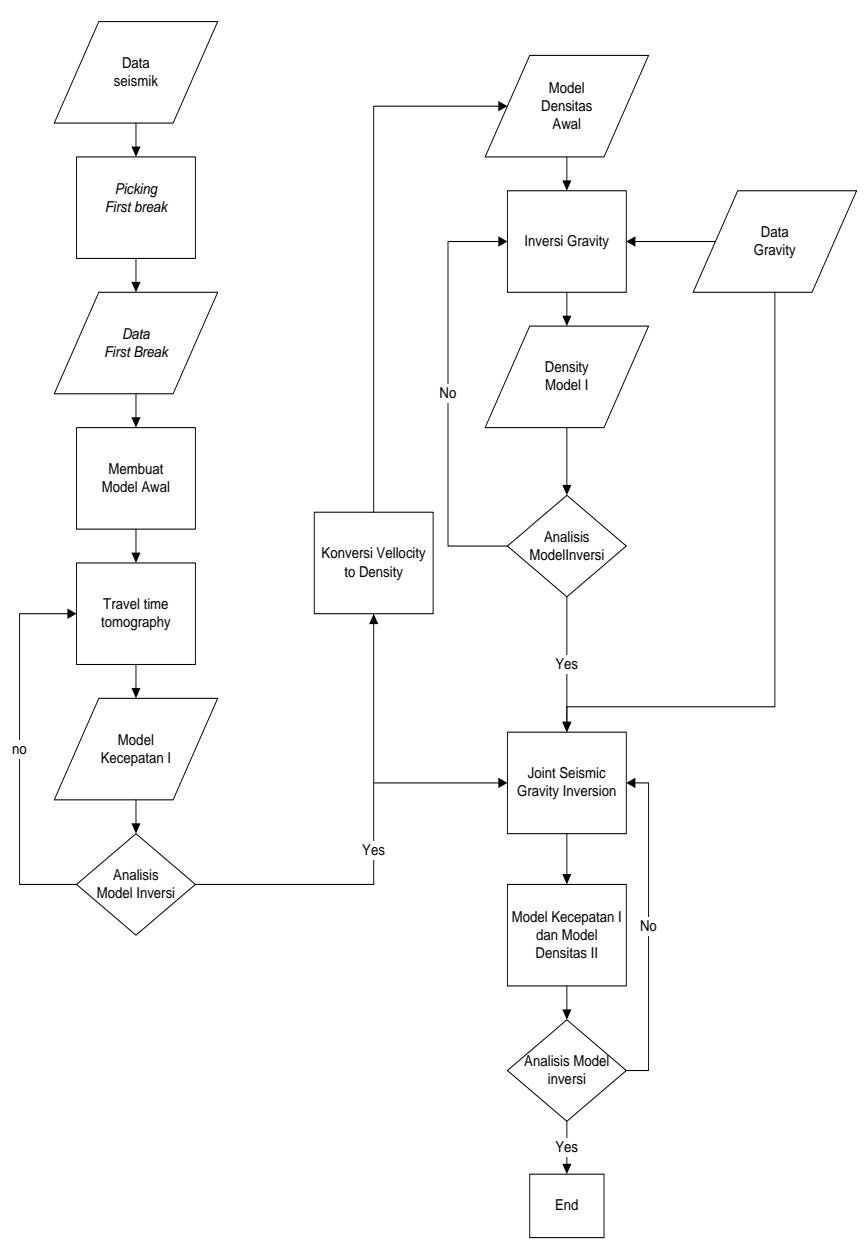

Gambar 2. Diagram alir imaging dengan Metode joint seismik dan gravity.

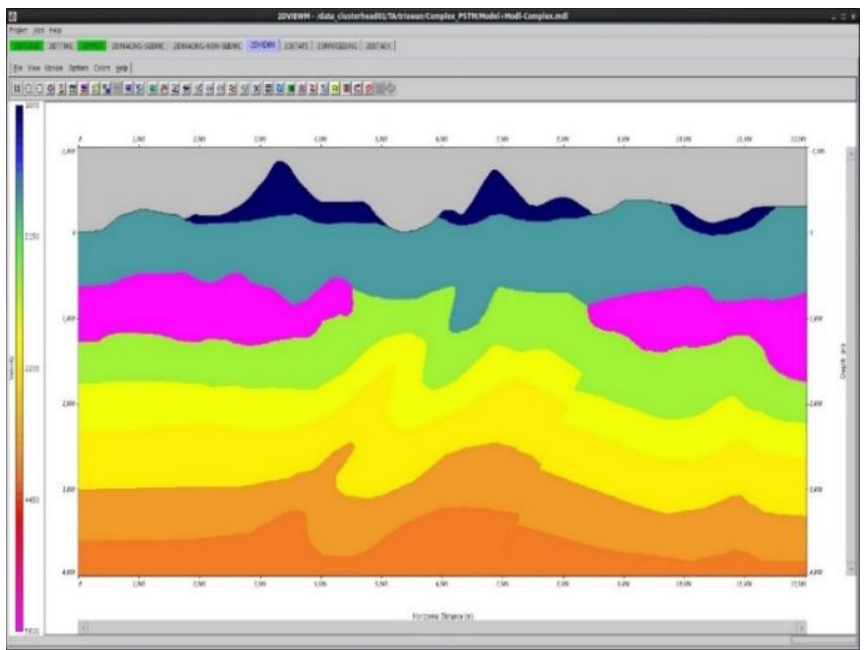

Gambar 3. Model kecepatan yang digunakan sitetik data seismik dan gravity pada penelitian.

\section{ANALISIS DATA DAN PEMBAHASAN}

\section{A. Travel Time Tomografi}

Travel time tomografi merupakan metode rekonstruksi kecepatan bawah permukaan. Pada kasus ini, gambar 4 merupakan inisial model yang digunakan dalam proses travel 
time tomografi. Model kecepatan tersebut akan deperbaiki pada proses tomografi travel time sehingga dihasilkan model kecepatan gambar 5.

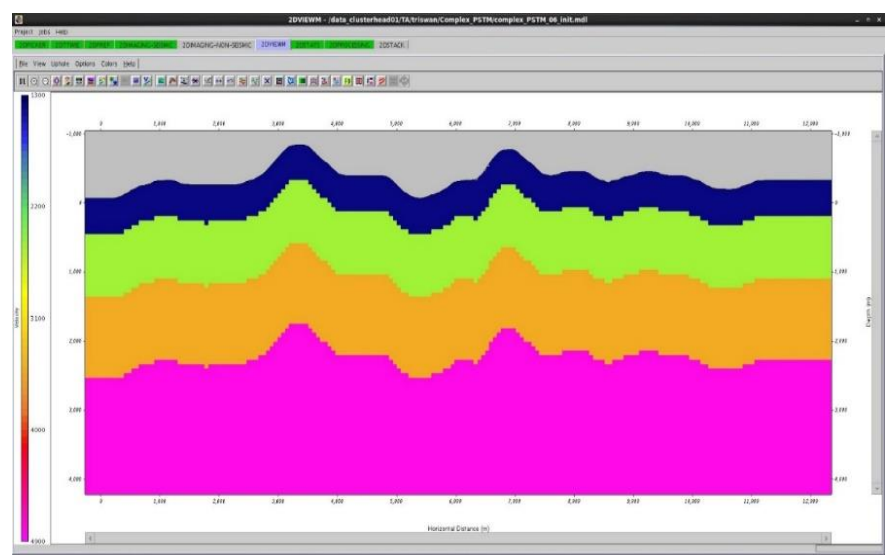

Gambar.4. Inisial model kecepatan tomografi travel time

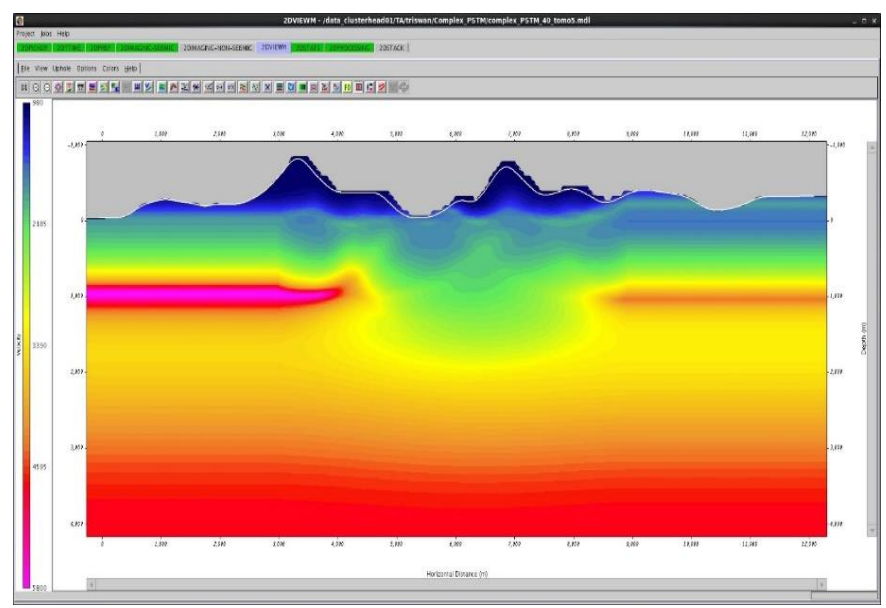

Gambar.5. Model kecepatan hasil tomografi travel time

Jika dibandingan model kecepatan pada gambar 5 dengan gambar 6 terlihat bahwa metode travel time tomografi tidak mampu merekonstruksi model kecepatan secara sempurna. Hal tersebut di tunjukkan pada bentuk tubuh batuan dengan kecepatan tinggi yang berada dalam lingkaran merah. Selain itu metode travel time tomografi tidak mampu merekonstruksi lapisan kecepatan rendah dekat permukaan yang berada di dalam lingkaran biru. Error model kecepatan yang didapatkan dari travel time tomografi sebesar $6.7 \mathrm{~ms}$.

\section{B. Inversi Gravity}

Model kecepatan hasil travel time tomografi kemudian di konversi kedalam parameter densitas dengan menggunakan persamaan hubungan densitas dan kecepatan oleh gardner. Model densitas hasil konversi tersebut menjadi inisial model pada proses inversi gravity

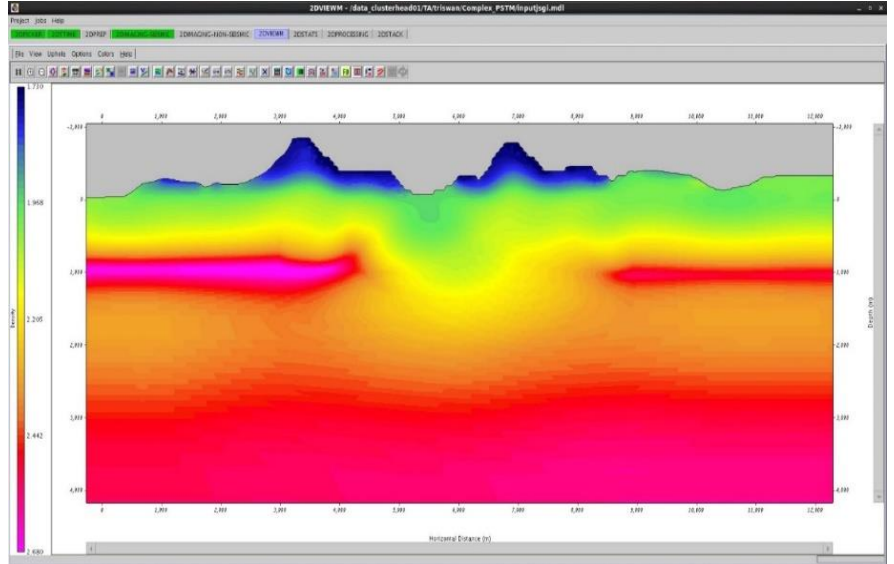

Gambar 6. Model Densitas hasil inversi gravity

Gambar 6 adalah model densitas hasil inversi gravity. Berdasarkan model tersebut pada inversi gravity lapisan kecepatan rendah tidak terlihat dalam garis biru akan tetapi bentuk lapisan kecepatan tinggi terlihat lebih baik jika dibandingkan hasil travel time tomografi. Error model densitas pada inversi gravity sebesar $5.3 \mathrm{mgal}$.

\section{Join Inversi Seismik-Gravity}

Model kecepatan dan densitas yang dihasilkan dari inversi seismik dan gravity digunakan sebagai inisial model untuk proses join inversi seismik-gravity.

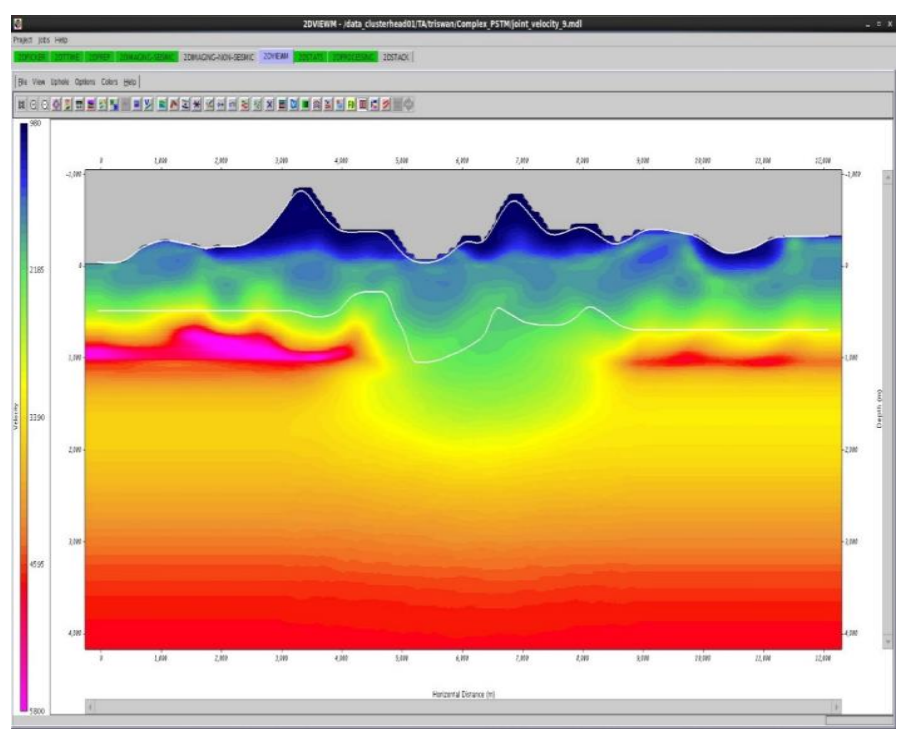

Gambar 7. Model kecepatan hasil join inversi seismik-gravity

Gambar.7. adalah model kecepatan hasil join inversi. Jika dibandingan model kecepatan hasil rekonstruksi travel time tomografi dengan join inversi pada gambar.5. terlihat bahwa model kecepatan hasil join inversi lebih baik. Keunggulan model kecepatan hasil join inversi terletak pada body batuan dengan kecepatan tinggi yang memiliki bentuk lebih baik dibandingkan dengan model travel time tomografi pada lingkaran merah dan bentuknya menyerupai dengan model sebenarnya pada gambar 3. Selain itu lapisan dengan kecepatan rendah pada lingkaran biru juga terlihat dan menyerupai bentuk pada real model gambar 3 . 


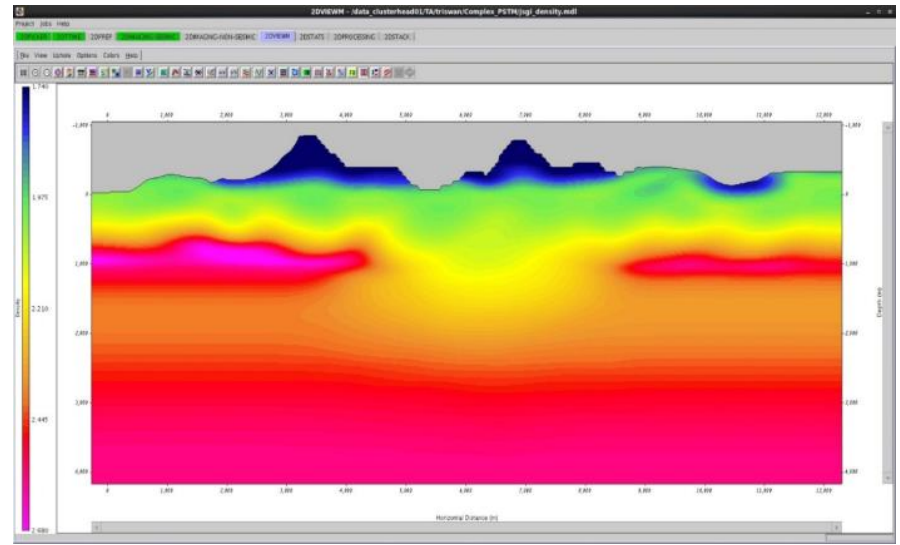

Gambar 8. Model Densitas hasil join inversi seismik-gravity

Gambar 8 jika dibandingkan dengan gambar 6 juga terlihat lebih baik, dari segi sensitifitas model densitas hasil inversi. Tubuh batuan kecepatan tinggi pada model densitah hasil join inversi telihat lebih baik dari segi bentuk dan ukuran. Selain itu lapisan kecepatan rendah dekat permukaan juga terlihat lebih jelas dan menyerupai gambar 3 .

\section{Koreksi Statik Join Inversi}

Model kecepatan hasil join inversi dan tomografi travel time digunakan sebagai input koreksi statik pada pengolahan data seismik. Kedua model tersebut dijadikan dasar penarikan posisi reflektor. Pada kasus ini metode koreksi statik konvensional seperti refraksi statik tidak dapat bekerja secara sempurna akibat keberadaan tubuh batuan kecepatan tinggi dekat permukaan.

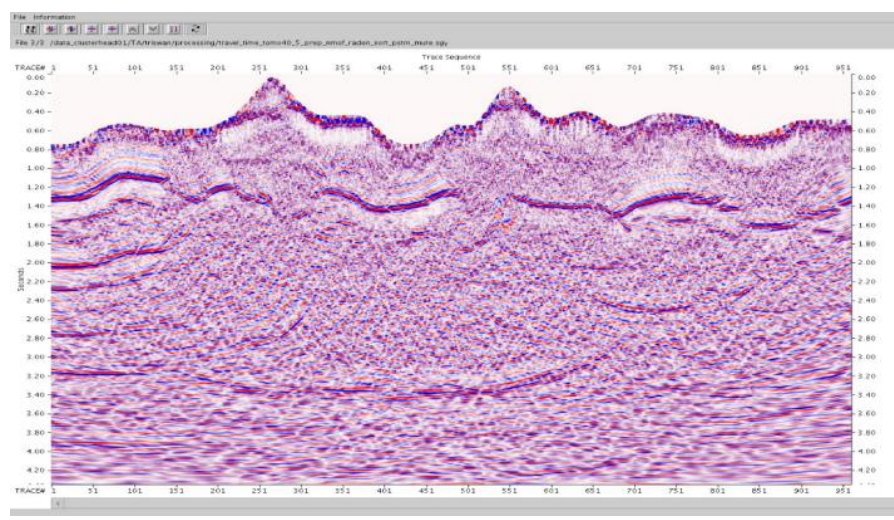

Gambar 9. Penampang seismik hasil koreksi statik dengan model kecepatan hasil tomografi travel time

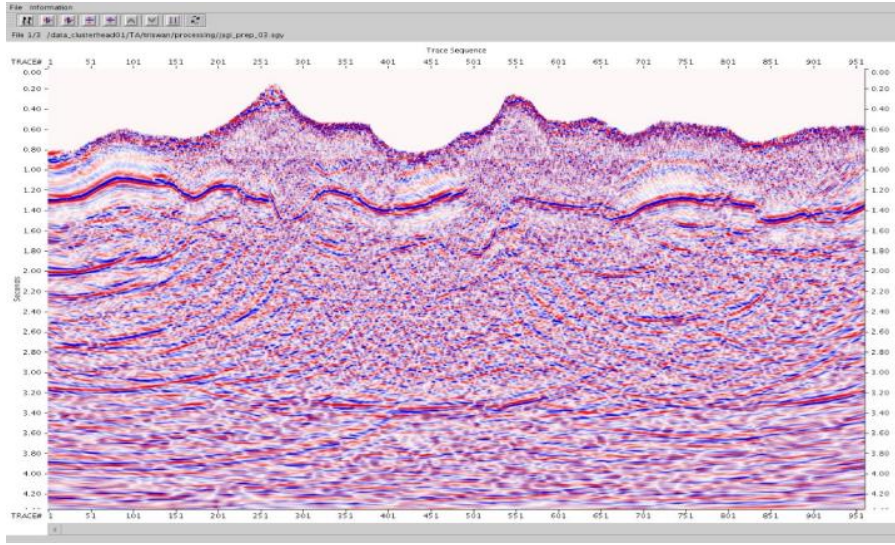

Gambar 10. Penampang seismik hasil koreksi statik dengan model kecepatan hasil join inveris seismik-gravity

Berdasarkan gambar 9 dan 10 reflektor yang berada dalam lingkaran merah pada penampang seismik statik join inversi lebih baik dari segi kemenerusan dan kemiringan reflektror. Hal trersebut diakibatkan karena model kecepatan join inversi memiliki sensitifitas lebih baik yang tunjukkan oleh bentuk tubuh batuan kecepatan yang lebih baik dan menyerupai model kecepatan sebenarnya.

\section{KESIMPULAN}

Kesimpulan penelitian penelitian mengenai aplikasi metode join inversi seismik gravity untuk imaging dan koreksi statik pada daerah geologi kompleks ialah:

1. Join seismik-gravity mampu memberikan model bawah permukaan yang lebih akurat di bandingkan dengan metode travel time tomografi hal tersebut terbukti pada kasus model sederhana dan kasus model complex PSTM dimana join inversi mampu memberikan nilai kecepatan yang benar pada lapisan kecepatan tinggi dan memunculkan anomaly dengan kecepatan rendah.

2. Koreksi satik yang dilakukan dengan model dari metode join inversi lebih baik dibandingkan dengan model dari travel time hal tersebut dibuktikan oleh kemenerusan, dipping, dan posisis reflektor yang lebih baik pada penampang seismik statik join inversi.

3. Join inversi seismik-gravity dan Travel time tidak mampu melakukan imaging dibawah batuan yang memiliki kecepatan tinggi dekat permukaan karena gelombang seismik tidak mampu melewati batuan tersebut sehingga tidak ada informasi refleksi ataupun refraksi untuk lapisan yang berada di bawah batuan tersebut.

\section{DAFTAR PUSTAKA}

[1] D. Colombo, D. R. (2013). 3D Seismic-gravity Simultaneous Joint Inversion. 75th EAGE Conference \& Exhibition incorporating SPE EUROPEC. London, UK: EAGE.

[2] Dengguo Zhou, D. R. (2014). 3D joint inversion of seismic traveltime and gravity data: a case study. SEG Annual Meeting. Denver: SEG.

[3] D. Colombo, M. M.-D. (2010). Near Surface Solution in South Rub AlKhali, Saudi Arabia appliying seismic-gravity joint inversion and redatiming. First Break. 